\title{
Lead as a Cause of SIDS
}

\section{Citation}

Lyngbye, Troels, O. N. Hansen, L. Vangbert, and P. Grandjean. 1985. "Lead as a cause of SIDS." The New England Journal of Medicine 313 (15): 954-955. doi:10.1056/NEJM198510103131511

\section{Published Version}

doi:10.1056/NEJM198510103131511

\section{Permanent link}

http://nrs.harvard.edu/urn-3:HUL.InstRepos:34216536

\section{Terms of Use}

This article was downloaded from Harvard University's DASH repository, and is made available under the terms and conditions applicable to Other Posted Material, as set forth at http:// nrs.harvard.edu/urn-3:HUL.InstRepos:dash.current.terms-of-use\#LAA

\section{Share Your Story}

The Harvard community has made this article openly available.

Please share how this access benefits you. Submit a story.

\section{Accessibility}


Previous attempts to demonstrate the presence of virus in circulating lymphocytes have been unrewarding. Measles virus antigens have been detected after stimulation with phytohemagglutinin in lymphocytes from a small number of patients with SSPE, and virus has been recovered from lymph-node biopsy specimens. ${ }^{8}$ These sporadic reports confirm the general view that lymphocytes become infected in the course of measles infection and a small number of these cells persist, although the type of cell affected and the nature of the viral imprint is not known. In vitro studies of human lymphocytes infected with measles virus have demonstrated both impaired killer-cell activity and impaired immunoglobulin synthesis. ${ }^{9}$ This occurs at a time when the lymphocytes appear normal and are not producing demonstrable measles-virus gene products.

If the majority of circulating lymphocytes contain viral genetic material similar to that present throughout the brain, then the challenge is to characterize better the type of lymphocyte involved and the chronology of that involvement. If these are $T$ cells, as suggested, the important next question is whether they are a specific subpopulation or possibly clonally derived. It seems unlikely that this number of circulating lymphocytes would acquire viral RNA as a result of exposure to virus in the nervous system. The reverse may be true, in the sense that infected lymphocytes may transmit virus to the brain at the time of the initial viremia. If these lymphocytes can be shown to be derived from a single clone, the disease mechanism may be linked in some way to that selection process, as originally proposed by Burnet. ${ }^{7}$ The gradual increase in the numbers of lymphocytes containing RNA sequences may be a factor influencing the onset of disease. Alternatively, if most of the lymphocytes were infected during the initial viremia, a transient state of immune suppression may have resulted, allowing virus to reach the central nervous system unchallenged. One might then argue that the remaining uninfected lymphocytes become sensitized by exposure to these cells, and that this accounts for the variable expression of cell-mediated immunity found in these patients.

Obviously, there are many questions remaining, and the final chapter of the SSPE story may not be written for years. However, the opportunity is now presented to examine the role of the immune system in this disease in greater detail. In so doing, we should learn how lymphocytes are affected by the presence of viral RNA, and possibly what the processes are of viral entry into these cells and of abortive viral replication. How lymphocytes interact with brain tissue and the role they may have in disease progression and arrest are questions that may now be answerable. In this regard it is probably timely to reexamine the lymphocytes from patients with multiple sclerosis, using similar hybridization techniques. Numerous studies over the years have suggested differences in the levels of measles antibodies in these patients as compared with control groups. Admittedly, these differences have not been great, and virus has not been detected in brain tissue. However, in measles virus encephalitis there is convincing evidence of white-matter involvement, without virus replication in the nervous system. ${ }^{10} \mathrm{Ob}$ viously, the nervous system reacts in a number of ways to infection with this virus, and the dependent variable is presumably the host's ability to respond at the time of the initial infection.

Although our knowledge of SSPE remains incomplete, substantial progress has been made in recent years and at a time when clinicians have forgotten about the condition because few new cases are occurring, at least in countries with comprehensive measlesimmunization programs. Nevertheless, a continued research effort to delineate the mechanism of this complex disease needs no defense, considering the relevance of what we may learn for a better understanding of both SSPE and other atypical viral infections of the human nervous system.

University of Tennessee

Memphis, TN 38103

John F. GRIFFith, M.D.

\section{REFERENCES}

1. Bouteille $M$, Fontaine $C$, Vedrenne $C$, Delarue J. Sur un cas d'encéphalite subaiguë à inclusions: etude anatomo-clinique et ultrastructurale. Rev Neurol 1965; 113:454-8.

2. Connolly JH, Allen IV, Hurwitz LJ, Millar JHD. Measles-virus antibody and antigen in subacute sclerosing panencephalitis. Lancet 1967; 1:542-4.

3. Payne FE, Baublis JV, Itabashi HH. Isolation of measles virus from cell cultures of brain from a patient with subacute sclerosing panencephalitis. N Engl J Med 1969; 281:585-9.

4. Hall WW, Choppin PW. Measles-virus proteins in the brain tissue of patients with subacute sclerosing panencephalitis: absence of the $M$ protein. N Engl J Med 1981; 304:1152-5.

5. Johnson KP, Norrby E, Swoveland P, Carrigan DR. Experimental subacute sclerosing panencephalitis: selective disappearance of measles virus matrix protein from the central nervous system. J Infect Dis 1981; 144:161-9.

6. Fournier JG, Tardieu M, Lebon P, et al. Detection of measles virus RNA in lymphocytes from peripheral-blood and brain perivascular infiltrates of patients with subacute sclerosing panencephalitis. N Engl J Med 1985; 313:910-5.

7. Burnet FM. Measles as an index of immunological function. Lancet 1968; 2:610-3.

8. Horta-Barbosa L, Hamilton R, Wittig B, Fuccillo DA, Sever JL, Vernon ML. Subacute sclerosing panencephalitis: isolation of suppressed measles virus from lymph node biopsies. Science 1971; 173:840-1.

9. Casali P, Rice GPA, Oldstone MBA. Viruses disrupt functions of human lymphocytes: effects of measles virus and influenza virus on lymphocytemediated killing and antibody production. J Exp Med 1984; 159:1322-37.

10. Johnson RT, Griffin DE, Hirsch RL, et al. Measles encephalomyelitis clinical and immunologic studies. N Engl J Med 1984; 310:137-41.

\section{CORRESPONDENCE}

\section{LEAD AS A CAUSE OF SIDS}

To the Editor: The sudden infant death syndrome (SIDS) is an enigmatic disease of unknown cause. Recent research suggests that a key to an understanding of its pathogenesis may be found by studying the survivors, or "near misses," of SIDS incidents.

From epidemiologic data, both environmental and social risk factors are known. ${ }^{1,2}$ The combination of risk indicators suggests that exposure to pollution may be important. Hoppenbrouwers et al. ${ }^{3}$ found a correlation with air-pollution factors, including lead, and Erickson et al. ${ }^{4}$ demonstrated an increased tissue concentration of lead in children with SIDS, as compared with the level in children who had died from other causes. 
Table 1. Summary Data on Three Children with an Episode of "Near-Miss" Sudden Infant Death.

\begin{tabular}{|c|c|c|c|c|c|}
\hline $\begin{array}{l}\text { CASE } \\
\text { No. }\end{array}$ & $\begin{array}{l}\text { AGE AT } \\
\text { EPISODE }\end{array}$ & $\begin{array}{c}\text { MONTH/TIME } \\
\text { ACTIVITY }\end{array}$ & $\begin{array}{l}\text { ACTION BY } \\
\text { CARETAKER }\end{array}$ & $\begin{array}{l}\text { DENTIN } \\
\text { LEAD* } \\
\mu g / g\end{array}$ & $\begin{array}{l}\text { Posstble Source } \\
\text { of Excess Lead }\end{array}$ \\
\hline 1 & 11 days & $\begin{array}{l}\text { March/11 p.m./ } \\
\text { sleep }\end{array}$ & $\begin{array}{l}\text { Vigorous stimulation, } \\
\text { contact with } \\
\text { family doctor }\end{array}$ & 26.9 & $\begin{array}{l}\text { Mother's occupation } \\
\text { (secretary in a } \\
\text { printing house) }\end{array}$ \\
\hline 2 & 8 months & $\begin{array}{l}\text { January/5 p.m./ } \\
\text { nap }\end{array}$ & $\begin{array}{l}\text { Resuscitation by profes- } \\
\text { sional nurse, trans- } \\
\text { fer to hospital }\end{array}$ & 21.1 & $\begin{array}{l}\text { Heavily trafficked road } \\
(35,000 \text { vehicles/day })\end{array}$ \\
\hline 3 & 12 days & $\begin{array}{l}\text { September } / 5 \text { p.m./ } \\
\text { nap }\end{array}$ & $\begin{array}{l}\text { Resuscitation by mother } \\
\text { and ambulance personnel, } \\
\text { transfer to hospital }\end{array}$ & 43 & $\begin{array}{l}\text { Father's occupation } \\
\text { (welder) }\end{array}$ \\
\hline
\end{tabular}

*The geographic mean of circumpulpal lead in Aarhus children is $8.9 \mu \mathrm{g}$ per gram. The limit used as "high" in the investigation was $\geqslant 18.7 \mu \mathrm{g}$ per gram, accounting for 8 per cent of the distribution.

In 1983-1984 first-grade children in the municipality of Aarhus, Denmark, were screened for lead absorption by measurement of the lead concentration in the secondary dentin of shed deciduous teeth. ${ }^{5}$ The screened cohort of 1302 children constituted 54 per cent of the eligible population. Children with the upper 8 per cent of tooth lead concentrations were selected and matched with children with the lowest concentrations, according to parental social group, sex, and school district.

A pediatrician who was blind to the lead data interviewed the parents about morbidity in the children, the medical background, and the possible sources of lead.

From interviews with 101 families of children with high levels of lead and 99 families of those with low levels, three cases of "nearmiss" SIDS were found; they all belonged to the high-level group (Table 1). Assuming a Poisson distribution, the 95 per cent confidence limits would be 0.62 to 8.77 .

The incidence of SIDS in Denmark is about 0.1 per cent. ${ }^{2}$ The incidence of "near-miss" SIDS is unknown, but according to clinical experience, it is probably similar.

The mothers of the three children had uncomplicated pregnancies and deliveries. There was no disposition to febrile convulsion or epilepsy and no recurrence of paroxysmal morbidity. The child in Case 2 was resuscitated by two professional nurses. Since convulsion or excretion was not observed, febrile convulsions were unlikely, although her temperature on arrival at the hospital was $39.3^{\circ} \mathrm{C}$.

Lead is a neurotoxic agent that passes the blood-brain and placental barriers. The developing nervous system is far more sensitive to lead than the adult nervous system. The toxic effect of lead on the respiratory center and the possible contribution of lead exposure to the occurrence of SIDS therefore requires thorough investigation.

Troels Lyngbye, M.D. Institute of Psychiatric Demography

Risskov, DK-8240, Denmark Ole Noerby Hansen, M.Psyck. Institute of Psychology

Aarhus, DK-8000, Denmark

Lilian Vangbert, M.D.

Philippe Grandjean, M.D., Ph.D. Institute of Community Health

Odense, DK-5000, Denmark

ear-SIDS. N Engl J Med 1982; 306:959Shannon DC,

2. Biering-Sørensen F, Jørgensen T, Hilden F. Sudden infant death in Copenhagen 1956-71. II. Social factors and morbidity. Acta Paediatr Scand 1979; 68:1-9.

3. Hoppenbrouwers T, Calub M, Arakawa K, Hodgman JE. Seasonal relationship of sudden infant death syndrome and environmental pollutants. Am J Epidemiol 1981; 113:623-35

4. Erickson MM, Poklis A, Gantner GE, Dickinson AW, Hillman LS. Tissue mineral levels in victims of sudden infant death syndrome. I. Toxic metals lead and cadmium. Pediatr Res 1983; 17:779-84.

5. Grandjean P, Hansen ON, Lyngbye K. Analysis of lead in circumpulpal dentin of deciduous teeth. Ann Clin Lab Sci 1984; 14:270-5. gen, a high partial pressure of carbon dioxide, and imposed fluctuations in cerebrovascular transmural pressure provoked periventricular hemorrhage ${ }^{2} ;$ (2) abnormalities of blood gases and blood pressure, and especially pneumothorax, were highly important and apparently causal antecedents of periventricular hemorrhage ${ }^{3-5}$; and (3) in a randomized controlled trial, muscle relaxation with pancuronium appeared to be safe (and beneficial for recovery of the lungs) in infants of 28 weeks' gestation or more who required mechanical ventilation for hyaline membrane disease. ${ }^{6}$ During that study, it was observed that a wide range of cardiorespiratory variables remained stable in the muscle-relaxed babies. These findings led to the conclusion that stabilization at normal levels of cardiorespiratory variables affecting cerebral hemodynamics was likely to be an effective and practical way of preventing periventricular hemorrhage. , $^{4,5}$

A randomized trial was therefore designed ${ }^{7}$ to test the hypothesis that muscle relaxation with pancuronium would reduce the incidence of periventricular hemorrhage. Unlike our previous trial, ${ }^{5}$ this trial, which was attempted in 1982, involved infants with gestational ages as low as 26 weeks, because the highest incidence of periventricular hemorrhage is to be found in the least mature infants. ${ }^{3-5}$ After 11 infants had been enrolled, we decided to abandon the trial, because in spite of careful monitoring and supervision, marked edema, serious derangements of fluid balance, and renal failure developed in two very immature pancuronium-tested infants, born at 27 and 29 weeks of gestation and weighing 710 and $1058 \mathrm{~g}$. Both infants died, and the smaller one was found to have bilateral periventricular leukomalacia. At the time that the trial was abandoned, four of the six musclerelaxed infants and three of five control infants had periventricular hemorrhage.

We think, therefore, that pancuronium may sometimes be hazardous in the least mature infants, because of unpredictable effects on circulating volume, blood pressure, and ventilatory requirements. Our concern about these effects is increased by the results of

Letters to the Editor are considered for publication (subject to editing and abridgment), provided that they are submitted in duplicate, signed by all authors, typewritten in double spacing, and do not exceed 40 typewritten lines of manuscript text (excluding references). Submission of a letter constitutes permission for the Massachusetts Medical Society, its licensees, and its assignees to use it in the Journal's various editions (print, data base, and optical disk) in anthologies, revisions, and any other form or medium. Letters should not duplicate similar material being submitted or published elsewhere, and they should not contain abbreviations. Financial associations or other possible conflicts of interest should always be disclosed.

Letters referring to a recent Journal article must be received within six weeks of the article's publication. We are unable to provide pre-publication proofs, and unpublished material will not be returned to authors unless a stamped, self-addressed envelope is enclosed. 